\title{
CHILDREN'S RIGHTS
}

\section{Multidisciplinary Approaches to Participation and Protection}

\author{
Edited by Tom O’Neill and Dawn Zinga
}

This volume explores the implications and implementation of the United Nations Convention on the Rights of the Child (CRC) in international and Canadian contexts. The Convention, adopted in 1989 and subsequently ratified by nearly all member nations, outlines the basic rights of all persons under the age of 18, provides tools for the improvement of the condition of the world's children, and sets out a global legal framework for the enactment of appropriate legislation and policy within individual countries.

The purpose of this collection of essays is to provoke critical debate in the social sciences about children's rights that goes beyond that found in the many prescriptive and programmatic works published to date. The principal argument is that children's rights, as defined by the CRC, provide an interdisciplinary framework from which the predicaments of children can be understood and acted upon. A recurrent theme is that children's participation rights, which are an important element of the Convention, remain unrecognized in practice yet are essential as a foundation for health, identity, and citizenship.

Organized in three parts, the volume begins with essays that address the status of children's rights as a framework for understanding children's predicaments around the world. The second part explores how the CRC is applied in efforts to protect children. The book concludes with discussion of how persisting barriers to the inclusion of disabled, bullied, and marginalized children can be understood as violations of their rights, and makes a strong case for children's participation as specified in article 12 of the Convention.

Featuring thirteen essays by distinguished and emerging scholars, Children's Rights provides an in-depth, multidisciplinary exploration of the major issues in the area of children's rights and will be an invaluable resource to scholars and practitioners working with children and youth in institutional and educational settings.

TOM O'NEILL and DAWN ZINGA are associate professors in the Department of Child and Youth Studies at Brock University. 
This page intentionally left blank 


\section{Children's Rights}

\section{Multidisciplinary Approaches to Participation and Protection}

Edited by Tom O'Neill and Dawn Zinga 
(C) University of Toronto Press Incorporated 2008

Toronto Buffalo London

www.utppublishing.com

Printed in Canada

ISBN 978-0-8020-9785-9 (cloth)

ISBN 978-0-8020-9540-4 (paper)

(6)

Printed on acid-free paper

\section{Library and Archives Canada Cataloguing in Publication}

Children's rights : multidisciplinary approaches to participation and protection / edited by Tom O'Neill and Dawn Zinga

ISBN 978-0-8020-9785-9 (bound) ISBN 978-0-8020-9540-4 (pbk.)

1. Children's rights. 2. Social participation. I. O'Neill, Tom, 1957-

II. Zinga, Dawn, 1971-.

\section{HQ789.C465 $2008 \quad 323.3^{\prime} 52 \quad$ C2008-901258-5}

University of Toronto Press acknowledges the financial assistance to its publishing program of the Canada Council for the Arts and the Ontario Arts Council.

University of Toronto Press acknowledges the financial support for its publishing activities of the Government of Canada through the Book Publishing Industry Development Program (BPIDP). 